\title{
POLITIK HUKUM ASAS NON-LEGALLY BINDING REKOMENDASI OMBUDSMAN REPUBLIK INDONESIA SEBAGAI INSTRUMEN PENCEGAHAN DAN PENANGANAN LAPORAN MALADMINISTRASI
}

\author{
Agung Ariyanto \\ Email: agungariyanto69@gmail.com \\ Mahasiswa Program Magister Ilmu Hukum \\ Fakultas Hukum Universitas Sebelas Maret Surakarta \\ Lego Karjoko \\ Email: Legokarjoko@staff.uns.ac.id \\ Dosen Fakultas Hukum Universitas Sebelas Maret Surakarta \\ Isharyanto \\ Email:masis_uns@yahoo.com \\ Dosen Fakultas Hukum Universitas Sebelas Maret Surakarta
}

\begin{abstract}
This study talk about analysis law political recommendations ombudsman that is not legally binding. Where in in law on Indonesian Ombudsman, this institution given the authority to made a mediation, reconciliation, and adjudication in decide maladministration. In terms of dispute resolution public service through adjudication ombudsman, ruling issued only to recommendations. The problem is how the power of these recommendations, for ombudsman is not institutions a court or forum court like the arbitration. The research is research law that is prescriptive with the approach the act and approach conceptual. Technique collection material law through the literature study and techniques analysis material law by using the method deduction. The results of this writing concluded to a weakness and lack of harmony between rules.
\end{abstract}

Keywords: Legal politic; non-legally binding; recommendation of Indonesia Ombudsma; public service.

\begin{abstract}
Abstrak
Tulisan ini membahas tentang analisis politik hukum rekomendasi Ombudsman Republik Indonesia yang bersifat tidak mengikat secara hukum (Non-Legally Binding). Di mana di dalam UU No. 37 Tahun 2008 tentang Ombudsman Republik Indonesia, institusi ini diberikan wewenang untuk melakukan mediasi, rekonsiliasi, dan ajudikasi dalam menyelesaikan perkara maladministrasi. Dalam hal penyelesaian sengketa pelayanan publik melalui ajudikasi Ombudsman, putusan yang dikeluarkan hanyalah sebatas rekomendasi. Persoalannya adalah bagaimanakah kekuatan rekomendasi ini, sebab Ombudsman bukanlah lembaga pengadilan atau forum pengadilan seperti halnya arbitrase. Penelitian ini merupakan penelitian hukum yang bersifat preskriptif dengan pendekatan undang-undang dan pendekatan konseptual. Teknik pengumpulan bahan hukum melalui studi pustaka dan teknik analisis bahan hukum dengan menggunakan metode deduksi. Hasil tulisan ini menyimpulkan adanya kelemahan dan ketidakharmonisan antara peraturan perundang-undangan antara, UU Pelayanan Publik, UU Ombudsman Republik Indonesia, dan Peraturan Ombudsman Republik Indonesia.
\end{abstract}

Kata Kunci: politik hukum;non-legally binding;rekomendasi Ombudsman Republik Indonesia; pelayanan publik. 


\section{A. Pendahuluan}

Undang-Undang Nomor 25 Tahun 2009 tentang Pelayanan Publik sudah lebih kurang 5 (lima) tahun diundangkan, namun beberapa survei yang dilakukan oleh beberapa lembaga menunjukkan rapor pelayanan publik Indonesia yang buruk. Hasil studi Political and Economic Risk Consultancy (PERC) tahun 2015 tentang tingkat korupsi di negara-negara tujuan investasi di kawasan Asia Pasifik menempatkan Indonesia dalam urutan kedua negara paling korup dari 16 negara yang disurvei. Selanjutnya, merujuk data Transparency International tahun 2015, peringkat Indeks Persepsi Korupsi (IPK) Indonesia naik dari tahun 2014 ke posisi 88 dari 168 negara yang disurvei dengan nilai IPK 36, namun tetap masih jauh di bawah negara-negara tetangga seperti Malaysia dan Singapura.

Dalam hal kemudahan berusaha (Ease OfDoing Business) yang dilansir oleh International Finance Corporation (IFC) menempatkan Indonesia pada peringkat 109 dari 189 negara atau berada pada peringkat ke-8 dari 10 negara ASEAN, hanya lebih baik dari Kambojadan Myanmar. Sementara itu, Indeks Daya Saing Global (Global Competitiveness Index/GCI) tahun 2014 - 2015 dari World Economic Forum (WEF) menyatakan posisiIndonesia di peringkat 37 dari 144 negara yang disurvei. WEF memprediksi kemajuandalam daya saing ini berkontribusi untuk memastikan keberlanjutan momentumpertumbuhan Produk Domestik Bruto (PDB) Indonesia yang mengesankan, namundemikian performa keseluruhan Indonesia dalam indeks ini tetap tidak berimbang (Bambang Sancoko, 2010: 43).

Infrastruktur dan juga konektivitas Indonesia terus-menerus naik peringkat di samping kualitas tata kelola publik dan swasta, serta efisiensi pemerintah. Namun demikian, Indonesia masih lemah dalam menangani pasar tenaga kerja, teknologi, kesehatan dan permasalahan pungli/suap dalam pelayanan publik.

Sejak awal berdirinya di Indonesia pada tahun 2000, Ombudsman kurang dikenal oleh masyarakat. Keberadaan Komisi Ombudsman Nasional yang sudah tujuh belas tahun belum mampu meraih tempat di hati masyarakat., bahkan bisa dikatakan sama sekali tidak populer. Apalagi jika dibandingkan KPK dan MK yang sama-sama lembaga baru. Padahal sebagai organ pendukung, keberadaan Ombudsman dirasa sangat penting untuk mewujudkan pelayanan publik yang baik. Kata Ombudsman berasal dari bahasa Swedia kuno yang memiliki arti perwakilan. Ombudsman dalam pengertian selanjutnya adalah seorang pejabat atau badan yang bertugas menyelidiki berbagai keluhan masyrakat.

Untuk menjawab pentingnya keberadaan Ombudsman, maka RUU Ombudsman RI disahkan oleh DPR RI menjadi Undang-Undang No. 37 Tahun 2008 tentang Ombudsman Republik Indonesia (UU ORI) dalam rapat paripurna DPR RI pada tanggal 9 Spetember 2008. Sejak itu status Ombudsman yang dulunya hanya komisi berubah menjadi lembaga negara (Adnan Buyung Nasution, 2012: 210).

Undang-Undang Nomor 37 Tahun 2008 memberi mandat kepada Ombudsman Republik Indonesia (ORI) untuk berperan sebagai lembaga pengawas eksternal pelayanan publik baik yang dilakukan oleh pemerintah termasuk BUMN, BUMD dan BHMN serta badan swasta atau perorangan yang diberi tugas menyelenggarakan pelayanan publik tertentu yang seluruhnya atau sebagian dananya berasal dari APBN atau APBD. Berdasarkan mandat, tugas, fungsi, dan wewenang ORI bekerja terus-menerus mendorong pemerintah selalu hadir dengan membangun tata kelola pemerintahan yang bersih, efektif, demokratis dan 
terpercaya, memperkuat dan membangun transparansi dan akuntabiltas kinerja pemerintah, serta pengawasan terhadap aksesibilitas dan kualitas pelayanan publik yang diberikan sebagai hak yang harus dipenuhi kepada masyarakat.

Dalam rangka menjalankan fungsi pengawasan tersebut, sejak 2013 ORI melakukan penilaian dan pemeriksaan tingkat kepatuhan di kementerian, lembaga, dan pemerintah daerah terhadap standar pelayanan publik. Hal ini sejalan dengan Rencana Pembangunan Jangka Menengah Nasional (RPJMN) 2015-2019 berdasarkan Peraturan Presiden Nomor 2 Tahun 2015, yang menempatkan langkah-langkah Pemerintah Pusat dan Pemerintah Daerah untuk mematuhi UU No 25 Tahun 2009 Tentang Pelayanan publik dalam peningkatan kualitas pelayanan public sebagai bagian dari proses penyempurnaan dan peningkatan kualitas Reformasi Birokrasi Nasional (RBN). Peraturan Presiden tersebut salah satunya menempatkan kepatuhan terhadap standar pelayanan publik sebagai salah satu target capaian RPJMN.

Fokus pemeriksaan tersebut dipilih karena standar pelayanan publik merupakan ukuran baku yang wajib disediakan oleh penyelenggara pelayanan sebagai bentuk pemenuhan asasasas transparansi dan akuntabilitas. Sebagaimana dinyatakan secara tegas dalam Pasal 54 UU Pelayanan Publik tersebut, terdapat sanksi mulai dari sanksi pembebasan dari jabatan sampai dengan sanksi pembebasan dengan hormat tidak atas permintaan sendiri bagi pelaksana dan penyelenggara pelayanan publik yang tidak memenuhi kewajiban menyediakan standar pelayanan publik yang layak.

Pengabaian terhadap standar pelayanan potensial mengakibatkan memburuknya kualitas pelayanan. Hal ini bisa diperhatikan melalui indikator-indikator kasat mata, misalnya jika tidak terdapat maklumat pelayanan yang dipampang maka potensi ketidakpastian hukum terhadap pelayanan publik akan sangat besar. Jika tidak terdapat standar biaya yang dipampang, maka potensi pungli, calo, dan suap menjadi lumrah di kantor tersebut. Pengabaian terhadap standar pelayanan publik juga akan mendorong terjadinya potensi perilaku maladministrasi dan perilaku koruptif. Dalam jangka panjang, pengabaian terhadap standar pelayanan publik potensial mengakibatkan menurunnya kredibilitas peranan pemerintah sebagai fasilitator, regulator, dan katalisator pembangunan pelayanan publik.

Pengabaian terhadap standar pelayanan publik juga akan mendorong terjadinya potensi perilaku maladministrasi dan perilaku koruptif yang tidak hanya dilakukan oleh Sumber Daya Manusia (SDM) Aparatur Pemerintah secara individu, namun juga secara sistematis melembaga terjadi di dalam instansi pelayanan publik karena pengabaian yang dilakukan oleh pimpinan instansi pelayanan publik terhadap ketentuan standar pelayanan publik.

Penilaian terhadap pemenuhan standar pelayanan tersebut dilakukan oleh Ombudsman Republik Indonesia dengan berpedoman pada kewenangannya yang secara tegas disebutkan dalam Pasal 8 Undang-Undang No. 37 Tahun 2008 tentang Ombudsman Republik Indonesia. Dalam penelitian kepatuhan, Ombudsman Republik Indonesia memposisikan diri sebagai masyarakat pengguna layanan yang ingin mengetahui hak-haknya dalam pelayanan publik, seperti ada atau tidaknya persyaratan pelayanan, kepastian waktu dan biaya, prosedur dan alur pelayanan, sarana pengaduan, pelayanan yang ramah dan nyaman, dan lain-lain. ORI tidak menilai bagaimana ketentuan terkait standar pelayanan itu disusun dan ditetapkan, sebagaimana telah dilakukan oleh lembaga lain. Penelitian ini juga tidak untuk menilai 
efektivitas dan kualitas pelayanan, serta kepuasan masyarakat terhadap pelayanan publik, melainkan hanya memfokuskan pada atribut standar layanan yang wajib disediakan pada setiap unit pelayanan publik. Atribut standar pelayanan yang disediakan oleh setiap unit layanan beragam bentuknya, ada yang berupa standingbanner, brosur, booklet, pamflet, media elektronik, dan masih banyak lainnya. Penilaian ORI tentu hanya berfokus pada atribut-atribut standar pelayanan yang sudah terpampang di ruang pelayanan, karena hal ini memudahkan masyarakat luas untuk mengakses dan mendapatkan standar pelayanan.

Setiap kementerian dan lembaga yang memiliki unit pelayanan wajib menyusun, menetapkan, dan menerapkan standar pelayanan publik sesuai perintah UU No. 25 Tahun 2009 tentang Pelayanan Publik, khususnya yang termaktub pada Bab V. Terdapat lebih dari 10 komponen standar pelayanan yang harus dipatuhi oleh penyelenggara pelayanan publik demi terciptanya kualitas pelayanan publik untuk kesejahteraan masyarakat.

Dua aspek penting dari komponen standar pelayanan tersebut menyangkut: a) hak masyarakat mendapatkan informasi yang cepat dan transparan; b) hak masyarakat mendapatkan akses dan fasilitas yang mudah dan layak. Ketersediaan informasi yang cepat dan transparan misalnya terkait dengan prosedur dan mekanisme pengurusan, persyaratan dokumen, biaya/tarif, jangka waktu penyelesaian, sarana pengukuran kepuasan pelanggan dan informasi mengenai prosedur dan tata cara pengaduan. Sedangkan terkait fasilitas atau sarana adalah misalnya ketersediaan toilet untuk pengguna layanan, sarana pengukuran kepuasan pelanggan, dan sarana khusus bagi pengguna layanan berkebutuhan khusus (ram, rambatan, kursi roda, jalur pemandu, toilet khusus, ruang menyusui, dll).

Kajian ini berfokus pada analisis politik hukum rekomendasi Ombudsman Republik Indonesia yang bersifat tidak mengikat secara hukum. Di mana di dalam UU No. 37 Tahun 2008 tentang Ombudsman Republik Indonesia, institusi ini diberikan wewenang untuk melakukan mediasi, rekonsiliasi, dan ajudikasi dalam menyelesaikan perkara maladministrasi. Adapun dalam hal ajudikasi, harusnya sebuah putusan yang dikeluarkan oleh yang berwenang harus memiliki kekuatan hukum sebagaimana yang dikeluarkan oleh pengadilan melalui putusan hakim. Tetapi dalam hal penyelesaian laporan maladministrasi yang diselesaikan melalui ajudikasi Ombudsman, hasil dari ajudikasi berupa rekomendasi sebagaimana yang tertuang di dalam Undang-Undang No. 37 Tahun 2008 tentang Ombudsman Republik Indonesia. Hal ini menimbulkan ketidakpastian hukum tentang kekuatan hukum dari sebuah putusan ajudikasi, yakni rekomendasi Ombudsman yang pada dasarnya tidak mengikat secara hukum dan belum bersifat final.

Berdasarkan hal di atas, maka dalam artikel ini hendak membahas tentang bagaimana politik hukum asas non-legally binding rekomendasi Ombudsman Republik Indonesia sebagai instrumen pencegahan dan penanganan laporan maladministrasi.

\section{B. Metode Penelitian}

Penelitian ini merupakan penelitian hukum doktrinal yang menggunakan metode studi kepustakaan. Bahan hukum yang digunakan adalah bahan hukum primer yang meliputi peraturan perundang-undangan mulai dari Undang-Undang Dasar Negara Republik Indonesia Tahun 1945, Undang-Undang, dan peraturan perundang-udangan lainnya yang terkait dengan masalah penelitian. Sumber informasi hukum mencakup juga bahan hukum sekunder seperti 
buku-buku referensi, majalah hukum, jurnal hukum, surat kabar, dan hasil karya ilmiah yang relevan dengan topik penelitian (Peter Mahmud Marzuki, 2014: 237-240).

\section{Hasil Penelitian dan Pembahasan}

Ombudsman adalah Mahkamah Pemberi Pengaruh (Magistrature of Influence) terhadap penyelenggara negara agar memperbaiki proses pemberian pelayanan umum(Jayashree Patill-Dake and Swati Mathur. 2010: 15). Alat untuk mempengaruhi penyelenggara negara tersebut antara lain adalah rekomendasi yang diberikan berdasarkan hasil investigasi Ombudsman. Apakah rekomendasi Ombudsman sama dengan rekomendasi seorang profesor yang mempromosikan seseorang untuk memperoleh beasiswa? Tentu saja berbeda, karena rekomendasi Ombudsman memiliki daya ikat moral yang jelas. Pejabat penyelenggara negara yang tidak mengikuti rekomendasi Ombudsman akan menghadapi berbagai konsekuensi tertentu. Oleh karena itu menarik untuk disimak tentang apa saja jenis dan tujuan rekomendasi Ombudsman, dan faktor apa saja yang mempengaruhi efektivitasnya.

Rekomendasi Ombudsman Republik Indonesia bukan merupakan saran biasa. Setelah melakukan rangkaian tahapan dalam investigasinya, Ombudsman akan segera menyusun rekomendasi. Rekomendasi antara lain diartikan sebagai saran (suggestion), namun kadangkala dapat juga berarti nasihat. Namun demikian, rekomendasi Ombudsman bukan sekedar saran atau nasihat biasa yang diberikan untuk pejabat publik, sebab di dalamnya terkandung nilai-nilai luhur kemanusiaan. Mengenai daya ikat moral dari rekomendasi Ombudsman, di dalam bukunya Budi Masthuri memaparkan ulasan mantan anggota Ombudsman yaitu Masdar F Masudi. Di mana di dalam tulisannya, Masdar F Masudi berpendapat bahwa mutu layanan Ombudsman sebagai fokus utama kerja Ombudsman adalah sesuatu yang lebih subtle, lebih lembut dan tidak serta merta dapat diukur dengan parameter legal formal atau dalam pasal-pasal yang rinci sekalipun. Kalaupun bisa diatur, tidak mungkin melalui aturan hukum dengan sanksi yang rigit dan proses peradilan yang rumit. Bahkan ada aspek layanan yang lebih halus lagi karena menyangkut dimensi norma kepatutan. Perlakuan tidak patut dalam proses pemberian pelayanan umum pada dasarnya adalah pelecehan terhadap martabat kemanusiaan dan tidak akan selesai bila diganti dengan jumlah uang seberapapun atau pelakunya diberi sanksi hukuman penjara seberat apapun. Di sinilah Ombudsman membangun paradigma baru dengan menempatkan pejabat publik sebagai manusia yang berbudi luhur.

Budaya hukum-menghukum (legally binding) adalah identik dengan budaya kekerasan. Dan hanya manusia dengan peradaban rendah yang suka akan kekerasan. Dengan demikian rekomendasi Ombudsman yang sifatnya Morally Binding pada dasarnya mencoba menempatkan manusia pada martabat mulia sehingga untuk melakukan sesuatu atau tidak melakukan sesuatu seorang pejabat publik tidak harus diancam dengan sanksi hukum, melainkan melalui kesadaran moral yang tumbuh dari lubuk hati paling dalam (Sunaryati Hartono, 2005: 38).

Untuk mendukung sistem morally binding, Ombudsman juga memiliki mekanisme laporan tahunan kepada parlemen yang dapat memberikan tekanan politik kepada eksekutif (politically impact). Sehingga meskipun bukan merupakan putusan pengadilan yang sifatnya 
legally binding, bukan berarti rekomendasi Ombudsman dapat diabaikan begitu saja. Politically Impact dari rekomendasi Ombudsman dapat terjadi karena adanya mekanisme pelaporan kepada Parlemen (DPR/DPRD) yang disampaikan Ombudsman setiap tahunnya. Dalam momen kasus tertentu, terhadap kasus yang berdimensi luas dan menyita perhatian publik, Ombudsman juga dapat menyampaikan laporannya kepada parlemen. Maka apabila terhadap kasus seperti itu ada aparat negara, pemeritah (daerah), atau peradilan yang tidak mengindahkan teguran dan saran daeri Ombudsman dapat disampaikan kepada parlemen (DPR/DPRD). Pada kesempatan tersebut, Ombudsman memiliki peluang untuk meminta agar DPR/DPRD mengusut masalah maladministrasi yang bersangkutan secara lebih lanjut, serta meminta pertanggungjawaban politis dari pimpinan pejabat publik terkait melalui panitia khusus atau panitia ad hoc lainnya yang prosedur dan mekanismenya tersedia dalam tata tertib di parlemen (Budhi Masthuri, 2005: 68).

Politically Impact dari Rekomendasi Ombudsman Republik Indonesia diatur di dalam Undang-Undang No. 37 Tahun 2008, yakni dalam Pasal 8 pada ayat (1) dan (2) yang berbunyi: Bahwa dalam menjalankan fungsi dan tugas sebagaimana dimaksud dalam Pasal 6 dan Pasal 7, Ombudsman berwenang:

a. Meminta keterangan secara lisan dan/atau tertulis dari Pelapor, Terlapor, atau pihak lain yang terkait mengenai Laporan yang disampaikan kepada Ombudsman;

b. Memeriksa keputusan, surat-menyurat, atau dokumen lain yang ada pada Pelapor ataupun Terlapor untuk mendapatkan kebenaran suatu Laporan;

c. Meminta klarifikasi dan/atau salinan atau fotokopi dokumen yang diperlukan dari

d. Instansi mana pun untuk pemeriksaan Laporan dari instansi Terlapor;

e. Melakukan pemanggilan terhadap Pelapor, Terlapor, dan pihak lain yang terkait dengan Laporan;

f. Menyelesaikan laporan melalui mediasi dan konsiliasi atas permintaan para pihak;

g. Membuat Rekomendasi mengenai penyelesaian Laporan, termasuk Rekomendasi untuk membayar ganti rugi dan/atau rehabilitasi kepada pihak yang dirugikan;

h. Demi kepentingan umum mengumumkan hasil temuan, kesimpulan, dan Rekomendasi.

Selain wewenang sebagaimana dimaksud pada ayat (1) di atas, Ombudsman berwenang:

a. menyampaikan saran kepada Presiden, kepala daerah, atau pimpinan Penyelenggara Negara lainnya guna perbaikan dan penyempurnaan organisasi dan/atau prosedur pelayanan publik;

b. menyampaikan saran kepada Dewan Perwakilan Rakyat dan/atau Presiden, Dewan Perwakilan Rakyat Daerah dan/atau kepala daerah agar terhadap undang-undang dan peraturan perundang-undangan lainnya diadakan perubahan dalam rangka mencegah Maladministrasi.

\section{Kekuatan Mengikat Putusan Ajudikasi (Rekomendasi) Ombudsman Republik Indonesia dalam Menangani Laporan Maladministrasi}

Sengketa Pelayanan Publik lahir dari adanya pengaduan dan/laporan masyarakat penerima pelayanan yang tidak puas atau merasa dirugikan oleh tindakan atau keputusan dari penyelenggaran pelayanan publik, yang ditujukan kepada penyelenggara pelayanan dan/atau pelaksana pelayanan, Ombudsman, dan/atau Dewan Perwakilan Rakyat, Dewan 
Perwakilan Rakyat Daerah Provinsi, Dewan Perwakilan Rakyat Daerah Kabupaten/Kota.

Proses penyelesaian sengketa Pelayanan Publik, berdasarkan Undang-undang Pelayanan Publik, dilakukan melalui beberapa jalan:

a. Proses penyelesaian sengketa pelayanan publik yang dilakukan di dalam dan oleh penyelenggara pelayanan publik itu sendiri. Dilaksanakan sesuai peraturan perundangan yang berlaku, dengan mengambil bentuk Administratief Beroep (upaya administratif), secara berjenjang berupa keberatan administratif dan banding administratif.

b. Proses penyelesaian sengketa pelayanan publik yang dilakukan oleh Ombudsman:

1) Mediasi dan/atau rekonsiliasi

2) Ajudikasi

c. Proses penyelesaian sengketa pelayanan publik yang dilakukan oleh Pengadilan Tata Usaha Negara (PTUN) bila pelayanan yang diberikan menimbulkan kerugian di bidang tata usaha negara.

Berdasarkan paparan tersebut di atas, berarti ajudikasi oleh Ombudsman dalam penyelesaian sengketa pelayanan publik hanyalah salah satu kemungkinan dari beberapa kemungkinan penyelesaian sengketa pelayanan publik. Mengingat fungsi Ombudsman sebagaimana diatur dalam Pasal 6, Undang-Undang Nomor 37 Tahun 2008 tentang Ombudsman Republik Indonesia yang berbunyi:

"Ombudsman berfungsi mengawasi penyelenggaraan pelayanan publik yang diselenggarakan oleh Penyelenggara Negara dan pemerintahan baik di pusat maupun di daerah termasuk yang diselenggarakan oleh Badan Usaha Milik Negara, Badan Usaha Milik Daerah, dan Badan Hukum Milik Negara serta badan swasta atau perseorangan yang diberi tugas menyelenggarakan pelayanan publik tertentu."

Hal ini berarti Ombudsman adalah lembaga Pengawas terhadap penyelenggaraan pelayanan publik, dan fungsi penyelesaian sengketa melalui ajudikasi adalah bagian dari fungsi pengawasan itu sendiri. Jadi Ombudsman bukanlah forum pengadilan. Seperti telah dibahas sebelumnya, ajudikasi adalah proses penyelesaian sengketa melalui peradilan atau lembaga yang menyelesaikan sengketa yang bersifat peradilan(Yuherman, 2010: 71). Dalam hal ini sengketa di antara para pihak akan diputus oleh pihak yang berkedudukan sebagai hakim, dan penyelesaian sengketa melalui suatu putusan hakim. Artinya dalam proses penyelesaian sengketa pelayanan publik yang dilakukan Ombudsman, Ombudsman akan berlaku sebagai hakim dan sebagai penyelesaian terhadap sengketa yang ada akan dikeluarkan putusan yang dalam hal ini dianggap sebagai putusan hakim yang berlaku bagi kedua belah fihak yang bersengketa. Hal ini sebenarnya tidak diatur sebagai salah satu kewenangan Ombudsman sebagaimana ketentuan Undang-Undang No. 37 Tahun 2008 tentang Ombudsman Republik Indonesia mengenai tugas dan wewenang Ombudsman, yaitu sebagaimana dijelaskan dalam Pasal 7 Ombudsman bertugas:

a. Menerima Laporan atas dugaan Maladministrasi dalam penyelenggaraan pelayanan publik;

b. Melakukan pemeriksaan substansi atas Laporan;

c. Menindaklanjuti Laporan yang tercakup dalam ruang lingkup kewenangan Ombudsman; 
d. Melakukan investigasi atas prakarsa sendiri terhadap dugaan Maladministrasi dalam penyelenggaraan pelayanan publik;

e. Melakukan koordinasi dan kerja sama dengan lembaga negara atau lembaga pemerintahan lainnya serta lembaga kemasyarakatan dan perseorangan;

f. Membangun jaringan kerja;

g. Melakukan upaya pencegahan Maladministrasi dalam penyelenggaraan pelayanan publik; dan

h. Melakukan tugas lain yang diberikan oleh undang-undang.

Pasal 8 ayat (1) Undang-Undang Ombudsman Republik Indonesia menyebutkan bahwa dalam menjalankan fungsi dan tugas sebagaimana dimaksud dalam Pasal 6 dan Pasal 7, yang pada intinya Ombudsman berwenang dalam hal:

a. Meminta keterangan secara lisan dan/atau tertulis dari Pelapor, Terlapor, atau pihak lain yang terkait mengenai Laporan yang disampaikan kepada Ombudsman;

b. Memeriksa keputusan, surat-menyurat, atau dokumen lain yang ada pada Pelapor ataupun Terlapor untuk mendapatkan kebenaran suatu Laporan;

c. Meminta klarifikasi dan/atau salinan atau fotokopi dokumen yang diperlukan dari instansi mana pun untuk pemeriksaan Laporan dari instansi Terlapor;

d. Melakukan pemanggilan terhadap Pelapor, Terlapor, dan pihak lain yang terkait dengan Laporan;

e. Menyelesaikan laporan melalui mediasi dan konsiliasi atas permintaan para pihak;

f. Membuat Rekomendasi mengenai penyelesaian Laporan, termasuk Rekomendasi untuk membayar ganti rugi dan/atau rehabilitasi kepada pihak yang dirugikan;

g. Demi kepentingan umum mengumumkan hasil temuan, kesimpulan, dan Rekomendasi.

Pada ayat (2) dijelaskan bahwa selain wewenang sebagaimana dimaksud pada ayat (1), Ombudsman juga berwenang dalam:

a. Menyampaikan saran kepada Presiden, kepala daerah, atau pimpinan Penyelenggara Negara lainnya guna perbaikan dan penyempurnaan organisasi dan/atau prosedur pelayanan publik;

b. Menyampaikan saran kepada Dewan Perwakilan Rakyat dan/atau Presiden, Dewan Perwakilan Rakyat Daerah dan/atau kepala daerah agar terhadap undang-undang dan peraturan perundang-undangan lainnya diadakan perubahan dalam rangka mencegah maladministrasi."

Ketentuan pasal 7 huruf h Undang-Undang Ombudsman, adalah hal yang merupakan pintu masuk bagi ketentuan Undang-Undang Pelayanan Publik untuk memberikan wewenang kepada Ombudsman untuk menjadi tempat penyelesaian sengketa pelayanan publik. Hal ini kemudian diatur lebih lanjut dalam Peraturan Ombudsman Republik Indonesia Nomor 26 Tahun 2017 tentang Tata Cara Penerimaan, Pemeriksaan, dan Penyelesaian Laporan, khusus mengenai ajudikasi diatur dalam pasal 38 dan Pasal 39. Tetapi kedua pasal tersebut tidak merinci secara jelas bagaimana prosedur pelaksanaan penyelesaian sengketa pelayanan publik secara ajudikasi. Ketentuan mengenai mediasi dan konsiliasi yang justru diatur secara terperinci dalam Peraturan Ombudsman. Padahal untuk tata cara Ajudikasi Ombudsman dalam penyelesaian sengketa pelayanan publik 
harus diatur dalam Peraturan Ombusman, sebagaimana ketentuan pasal 50 ayat (7) UU Pelayanan Publik yang berbunyi:

"Dalam melaksanakan ajudikasi khusus sebagaimana dimaksud pada ayat (5), mekanisme dan tata caranya diatur lebih lanjut oleh peraturan Ombudsman."

Hal ini menjadi suatu hal yang dapat menjadi pembahasan secara teoritis sambil menunggu diterbitkannya Peraturan Ombudsman mengenai ajudikasi dalam penyelesaian sengketa pelayanan publik. Secara umum ajudikasi yang akan diselenggarakan oleh Ombudsman berpotensi menimbulkan beberapa masalah, terutama bila melihat adanya putusan, serupa putusan pengadilan, sebagai hasil akhir dalam penyelesaian sengketa pelayanan publik ini. Persoalannya adalah bagaimanakah kekuatan putusan ini, sebab Ombudsman bukanlah lembaga pengadilan atau forum pengadilan seperti halnya arbitrase (H. M. N. Purwosutjipto, 1992: 1). Ketentuan Pasal 1 angka 7 Undang-undang Ombudsman mengatur bahwa hasil investigasi Ombudsman adalah Rekomendasi, yaitu:

"Rekomendasi adalah kesimpulan, pendapat, dan saran yang disusun berdasarkan hasil investigasi Ombudsman, kepada atasan Terlapor untuk dilaksanakan dan/ atau ditindaklanjuti dalam rangka peningkatan mutu penyelenggaraan administrasi pemerintahan yang baik."

Hal ini menunjukkan bahwa produk Ombudsman dalam penyelesaian permasalahan yang dilaporkan kepada Ombudsman (termasuk sengketa pelayanan publik) tidaklah berbentuk "putusan", melainkan rekomendasi. Memang rekomendasi Ombudsman "bersifat wajib", sebagaimana ketentuan pasal 38 ayat (1) yang berbunyi: "Terlapor dan atasan Terlapor wajib melaksanakan Rekomendasi Ombudsman. "

Serta ketentuan pasal Pasal 39 dan Pasal Undang-undang Ombudsman yang berbunyi: "Terlapor dan atasan Terlapor yang melanggar ketentuan sebagaimana dimaksud dalam Pasal 38 ayat (1), ayat (2), atau ayat (4) dikenai sanksi administrasi sesuai dengan ketentuan peraturan perundang-undangan."

Adanya ketetentuan penjatuhan sanksi administrasi bagi pihak yang mengabaikan rekomendasi Ombudsman, menunjukan bahwa rekomendasi Ombudsman sekalipun bukan merupakan suatu Keputusan Tata Usaha Negara (Antonius Sujata 2009: 56), karena Ombudsman bukanlah bagian dari lembaga eksekutif(Tata Usaha Negara), sebagaimana ketentuan Pasal 2 Undang-undang Ombudsman, yang berbunyi:

"Ombudsman merupakan lembaga negara yang bersifat mandiri dan tidak memiliki hubungan organik dengan lembaga negara dan instansi pemerintahan lainnya, serta dalam menjalankan tugas dan wewenangnya bebas dari campur tangan kekuasaan lainnya."

Tetapi dalam pelaksanaan hasil rekomendasinya Ombudsman tergantung kepada kehendak dan kemauan baik dari Tata Usaha Negara yang menerima rekomendasi tersebut. Lebih lanjut dapat disimpulkan bahwa rekomendasi Ombudsman sekalipun "bersifat wajib" tetapi belum tentu memiliki sifat "final dan mengikat" (final and binding) seperti halnya putusan dari proses ajudikasi baik di pengadilan maupun di arbitrase. Apalagi bila kita kaitkan dengan adanya ketentuan penjatuhan sanksi administrasi bagi pihak yang mengabaikan rekomendasi Ombudsman, baik terlapor sendiri atau atasan dari terlapor. Artinya terhadap rekomendasi Ombudsman dapat diperlakukan upaya administrasi lebih lanjut. 
Hal ini tentu berdampak pada putusan ajudikasi Ombudsman dalam penyelesaian sengketa pelayanan publik atau khususnya maladministrasi. Putusan ajudikasi ini bila dilihat sebagai hasil kerja Ombudsman, tentunya bernilai sama dengan rekomendasi, padahal secara hukum harusnya berbeda. Sehingga putusan ajudikasi Ombudsman dalam penyelesaian sengketa pelayanan publik memiliki kekuatan hukum hanya sebagai rekomendasi.

\section{Upaya Hukum Terhadap Putusan Ajudikasi Ombudsman Dalam Proses Penyelesaian Sengketa Pelayanan Publik}

Berdasarkan pembahasan sebelumnya, dinyatakan bahwa, kekuatan mengikat putusan ajudikasi Ombudsman dalam penyelesaian sengketa pelayanan publik memiliki kekuatan hukum hanya sebagai rekomendasi, maka sudah tentu terhadap putusan tersebut dapat dilakukan upaya hukum lebih lanjut. Upaya hukum itu dapat dilaksanakan dengan beberapa kemungkinan, yaitu:

a. Mekanisme dalam Undang-undang Pelayanan Publik, karena proses penyelesaian sengketa pelayanan publik adalah bagian dari pengaduan dan dan pelaporan dari masyarakat terhadap pelayanan publik yang dilakukan oleh penyelenggara dan/ atau pelaksana pelayanan publik. Upaya hukum yang dapat dilakukan adalah, bila hasil putusan ajudikasi Ombudsman tersebut diabaikan/tidak dilaksanakan oleh terlapor, maka terlapor dapat dilaporkan kepada instansi atasannya, dan terhadap yang bersangkutan dapat dikenai sanksi administrasi berupa teguran, penuruan gaji, penurunan jabatan, sampai pembebasan dari jabatan, dengan maksud agar pihak terlapor mau melaksanakan putusan ajudikasi Ombudsman. Upaya hukum ini serupa dengan bentuk administrateif beroep. Bila ternyata pada pihak yang mengabaikan putusan ajudikasi itu ditemukan adanya perbuatan melawan hukum atau tindak pidana, maka pihak tersebut dapat diajukan ke muka Pengadilan Tata Usaha Negara dan/atau Pengadilan Umum.

b. Mekanisme dalam undang-undang Ombudsman dan Peraturan Ombudsman Republik Indonesia Nomor 26 Tahun 2017 tentang Tata Cara Penerimaan, Pemeriksaan, dan Penyelesaian Laporan, dalam hal terlapor mengabaikan rekomendasi Ombudsman, berlaku ketentuan pasal 38 ayat (4) Undang-Undang Ombudsman, yang berbunyi: "Dalam hal Terlapor dan atasan Terlapor tidak melaksanakan Rekomendasi atau hanya melaksanakan sebagian Rekomendasi dengan alasan yang tidak dapat diterima oleh Ombudsman, Ombudsman dapat mempublikasikan atasan Terlapor yang tidak melaksanakan Rekomendasi dan menyampaikan laporan kepada Dewan Perwakilan Rakyat dan Presiden."

Ketentuan ini diatur lebih lanjut dalam pasal 41 Peraturan Ombudsman Republik Indonesia Nomor 26 Tahun 2017 tentang Tata Cara Penerimaan, Pemeriksaan, dan Penyelesaian Laporan yang berbunyi:

a. Ombudsman dapat meminta keterangan Terlapor dan/atau atasan Terlapor, dan melakukan pemeriksaan lapangan untuk memastikan pelaksanaan Rekomendasi,

b. Pemantauan pelaksanaan rekomendasi dilaksanakan dalam rentang waktu 60 hari kerja terhitung sejak tanggal diterimanya Rekomendasi.

c. Ombudsman melakukan pemantauan pelaksanaan Rekomendasi oleh Terlapor dab/ 
atau Atasasn Terlapor untuk menyatakan Terlapor dan/atau Atasan Terlapor telah melaksanakan Rekomendasi, melaksanakan sebagian Rekomendasi atau tidak melaksanakan Rekomendasi,

d. Apabila dalam waktu 60 (enam puluh) hari kerja Rekomendasi tidak dilaksanakan atau dilaksanakan sebagian, dan dengan alas an yang tidak patut, Ombudsman menyampaikan Rekomendasi Penjatuhan Sanksi kepada pejabat 2 (dua) tingkat di atas Terlapor atau pejabat yang dapat menjatuhkan sanksi administratif,

e. Apabila Terlapor dan/atau Atasan Terlapor tidak melaksanakan Rekomendasi, atau hanya melaksanakan sebagian Rekomendasi, Ombudsman dapat menyampaikan laporan kepada DPR dan Presiden atau DPRD dan Kepala Daerah.

f. Ombudsman dapat mempublikasikan Terlapor dan/atau Atasan Terlapor yang tidak melaksanakan Rekomendasi atau melaksanakan sebagian Rekomendasi tanpa alas an yang patut oleh Ombudsman.

g. Prosedur monitoring Rekomendasi diatur lebih lanjut dengan Keputusan Ketua Ombudsman.

Terhadap pihak yang mengabaikan rekomendasi ini, dapat dikenai sanksi administrasi sebagaimana ketentuan pasal 39 UU Ombudsman. Berdasarkan ketentuan tersebut, dapat disimpulkan terhadap rekomendasi Ombudsman upaya hukum lebih lanjutnya adalah mekanisme upaya administratif yang berujung dengan penjatuhan sanksi administrasi, dan berdasarkan pembahasan di atas, hal tersebut menguatkan asumsi bahwa penyelesaian sengketa pelayanan publik melalui mekanisme ajudikasi di Ombudsman masih harus dikaji lebih lanjut.

\section{Simpulan}

Proses penyelesaian perkara Maladministrasi pelayanan publik oleh Ombudsman Republik Indonesia melalui pemberian Rekomendasi yang berasaskan non-legally binding perlu banyak evaluasi. Rekomendasi Ombudsman Republik Indonesia yang tidak mengikat secara hukum dan tidak bersifat final dipandang kurang efektif dalam menyelesaikan perkara maladministrasi. Dewasa ini maladministrasi dipahami sebagai gerbang awal tindakan melawan hukum baik korupsi, kolusi, dan nepotisme. Di mana dalam hal maladministrasi penyelenggaraan pelayanan publik, masyarakat sebagai konsumen pelayanan publik menjadi subjek yang merasakan langsung dampak dari tindakan melawan hukum tersebut. Terkait hal tersebut, upaya hukum yang dapat dilakukan dalam hal menindaklanjuti pelanggaran rekomendasi Ombudsman adalah melalui penjatuhan sanksi administrasi, yang pada hakikatnya belum bersifat final dan mengikat. Sehingga dalam tulisan ini disimpulkan perlu adanya kajian lebih lanjut terkait mekanisme penanganan maladministrasi melalui rekomendasi Ombudsman Republik Indonesia.

\section{E. Saran}

Tingkat kepatuhan penyelenggara negara dalam hal pemenuhan standar pelayanan publik masih belum mencapai titik yang diharapkan. Hal ini bisa dijadikan tolak ukur sejauh mana urgensi pembahasan revisi peraturan perundang-undangan baik menyangkut 
tentang Pelayanan Publik maupun lembaga pengawas sepeti halnya Ombudsman Republik Indonesia. Asas non-legally binding rekomendasi Ombudsman Republik Indonesia patut untuk dipertahankan, namun perlu adanya kajian lebih lanjut terkait mekanisme pertanggung jawaban hukum dan pengawasan pelayanan publik baik dari internal, maupun eksternal sebagiamana yang dilakukan Ombudsman selama ini. Sehingga target yang ingin dicapai dalam menyejahterakan bangsa dan negara bisa segera tercapai secara efektif dan efisien.

\section{F. Daftar Pustaka}

Adnan Buyung Nasution. 2012. Nasihat Untuk SBY. Jakarta: Kompas Gramedia.

Antonius Sujata. dkk. 2009. Ombudsprudensi. Jakarta: Ombudsman Republik Indonesia.

Bambang Sancoko. 2010. "Bisnis \& Birokrasi" artikel dalam Jurnal Ilmu Administrasi dan Organisais. Volume 17 Nomor 1.

Budhi Masthuri. 2005. Mengenal Ombudsman Indonesia.Jakarta: Pradnya Paramitha.

H.M.N. Purwosutjipto. 1992. Pokok-pokok Hukum Dagang, Perwasitan, Kepailitan dan Penundaan Pembayaran. Cetakan III. Jakarta: Djambatan.

Jayashree Patill-Dake and Swati Mathur. 2010. "Banking Ombudsman: Protection to Consumer”, artikel dalam Abhinav National Monthly Refereed Journal of Research in Commerce \& Management. Volulme 1 Number 1.

Peter Mahmud Marzuki. 2014. Penelitian Hukum. Jakarta: Penerbit Prenadamedia Group.

Sunaryati Hartono.2005.Peranan Ombudsman Dalam Pemberantasan dan Pencegahan Korupsi serta Pelaksanaan Pemerintahan yang Baik. Jakarta: Komisi Ombudsman Nasional.

Yuherman. 2010. "Politik Hukum Peradilan dalam Praktek Penyelesaian Sengketa". artikel dalam Jurnal Yustisia. edisi No. 81. 